\title{
Ketamine Sedation of Case with Unknown Posterior Fossa Tumor
}

\section{Posterior Fossa Tümörü Olduğu Bilinmeyen Olguda Ketamin Sedasyonu}

Bengü Gülhan Aydın, Mehmet Akın*, Gamze Küçükosman, Murat Çimencan, Özcan Pişkin, Dilek Okyay, Hilal Ayoğlu

Bülent Ecevit University Faculty of Medicine, Department of Anesthesiology and Reanimation, Zonguldak, Turkey

*Bartın State Hospital, Clinic of Anesthesiology and Reanimation, Bartın, Turkey

\section{Abstract}

Ketamine, chosen for many years for anesthetic practice, is the only agent with analgesic, hypnotic and amnesic effects. Since the use of ketamine may cause uncontrolled increases in intracranial pressure, in the literature, there are concerns about its use, especially for patients with increased intracranial pressure. In this article, we aimed to present the case of a patient with an unknown posterior fossa tumor who did not recover after ketamine administered for sedation.

Keywords: Ketamine, sedation, intracranial mass

\section{Introduction}

Ketamine is frequently preferred intravenous (iv) anesthetic agent because it provides minimal respiratory depression and powerful analgesia. Ketamine should not be used alone or without taking other precautions for patients with intracranial pathologies since it also has cerebral vasodilatator effects and increases blood flow and oxygen consumption (1).

Posterior fossa tumors represent $45-60 \%$ of the central nervous system tumors in childhood. Masses in this region can compress the brain stem or lead to compression by pushing up the tentorium. The symptoms are linked to increased intracranial pressure (ICP) or hydrocephalus as an interruption in the cerebrospinal fluid can cause confusion in these patients (2). In this paper, we present the case of a patient with an unknown posterior fossa tumor who did not recover after ketamine administered for sedation.
Öz

Anestezi pratiğinde uzun ylllardan beri tercih edilmekte olan ketamin, analjezik, hipnotik ve amnezik etkileri olan tek ajandır. Literatürde ketamin kullanımının kontrol edilemeyen kafa içi basınç artışlarına yol açması nedeniyle özellikle artmış kafa içi basıncı olan hastalarda kullanımı ile ilgili endişeler mevcuttur. Yazımızda posterior fossa tümörü olduğu bilinmeyen, sedasyonu için ketamin uygulanması sonucu derlenemeyen olgunun sunulması amaçlanmıştır.

Anahtar Sözcükler: Ketamin, sedasyon, intrakraniyal kitle

\section{Case}

A 6-year-old boy weighing $18 \mathrm{~kg}$ was referred to our hospital for emergency intracranial mass operation. Physical examination of the patient showed poor general condition. Glasgow coma scale (GCS) score was 4, blood pressure-110/64 $\mathrm{mmHg}$, pulse- $93 / \mathrm{min}$, and pulse oximeter was $98 \%$. Natural respiratory sounds and rhythmic heart beats were noted. Cranial computed tomography showed a $4.7 \times 4 \mathrm{~cm}$ hyperdense mass in the cerebellum lateralized to the right of the midline; the $4^{\text {th }}$ ventricle could not be imaged. Emergency intracranial mass excision was planned. According to the epicrisis report, the patient had a history of fatigue, headache, and nausea-vomiting 15 days ago; after complaints had resolved, the patient was taken for circumcision at another hospital under elective conditions with American Society of Anesthesiologists physical status class I. After routine monitoring, $2 \mathrm{mg}$ midazolam and $2 \mathrm{mg} / \mathrm{kg}$ ketamine iv were administered
Address for Correspondence/Yazışma Adresi: Bengü Gülhan Aydın

Bülent Ecevit University Faculty of Medicine, Department of Anesthesiology and Reanimation, Zonguldak, Turkey E-mail: bengukoksal@gmail.com

Received/Geliş Tarihi: 05 February 2016 Accepted/Kabul Tarihi: 12 February 2016
The Medical Bulletin of Haseki Training and Research Hospital, published by Galenos Publishing.

Haseki Tıp Bülteni, Galenos Yayınevi tarafından basılmıştır. 
and the vital signs were stable during the operation. In the recovery period, the patient was sleepy, when his GCS score regressed to 11, cranial tomography was taken which showed a cerebellar mass, and the patient was referred to our hospital. Emergency posterior fossa surgery was planned. Electrocardiogram, pulse oximetry, heart rate, noninvasive arterial blood pressure, and end-tidal carbon dioxide $\left(\mathrm{ETCO}_{2}\right)$ monitoring was done in the patient who underwent emergency posterior fossa surgery. Anesthesia was induced with iv lidocaine $1 \mathrm{mg} / \mathrm{kg}$, propofol $2.5 \mathrm{mg} /$ $\mathrm{kg}$, fentanyl $1 \mu \mathrm{g} / \mathrm{kg}$, and rocuronium $0.6 \mathrm{mg} / \mathrm{kg}$ and was maintained with $2 \%$ sevoflurane in $50 \%$ air and oxygen and remifentanil infusion. We preferred controlled mechanical ventilation for our patient. Intraoperative vital signs were stable, appropriate fluid and blood replacement and brain edema treatments were administered. The operation was uneventful. After the operation, the patient was taken to the intensive care unit with a GCS of three while still being intubated. Monitored on a ventilator, the patient was exitus on the postoperative day 11 .

\section{Discussion}

Ketamine is a sedative-hypnotic agent with potent analgesic properties (3). It is used for sedation and analgesia in induction of general anesthesia and perioperative period. Under appropriate sedation with controlled ventilation conditions, ketamine does not increase ICP, however, when given at $2 \mathrm{mg} / \mathrm{kg}$ or above in awake children and adults, it increases ICP and, especially, if there is high ICP this increase is more pronounced. These patients have effective respiration as $\mathrm{ETCO}_{2}$ and arterial $\mathrm{CO} 2$ do not increase and it is stated that nearly all have obstructed ventricular system (due to no shunt or shunt not working) (4-8).

Case reports related to increased ICP due to ketamine were published in 1970-1972. Gardner et al. (4) reported that in a 13-year-old patient with the diagnosis of glioma, nausea-vomiting at intervals and midline shift with spontaneous respiration, who was administered $2 \mathrm{mg} / \mathrm{kg}$ ketamine to take pneumoventriculography, ICP increased from $42 \mathrm{cmH}_{2} \mathrm{O}$ to $107.5 \mathrm{cmH}_{2} \mathrm{O}$. Lockhart and Jenkins (5) administered 50 mg intramuscular ketamine to a pediatric patient with ICP symptoms to insert a ventriculoperitoneal shunt and found that after induction, apnea developed. They stated that if ketamine is administered in the presence of increased ICP, clinicians should to be more careful for possible side effects.

Belopavlovic and Buchthal (9) reported that $1 \mathrm{mg} /$ $\mathrm{kg}$ ketamine administered after midazolam or diazepam induction in patients with brain tumors or hydrocephalus, increased ICP and that in superficial anesthesia, this increase was more pronounced after muscle relaxants and tracheal intubation.

Mayberg et al., (10) stated that administering $1 \mathrm{mg} /$ $\mathrm{kg}$ ketamine to patients with high ICP and diagnosis of supratentorial tumor and aneurysm, under isoflurane $(0.4 \%)$ and $50: 50 \%$ nitrous oxide/oxygen anesthesia with moderate hypocapnia $(34 \pm 1 \mathrm{mmHg})$, did not increase ICP and mean arterial pressure.

Benzodiazepines reduce cerebral blood flow and ICP, depress the ventilatory response to $\mathrm{CO}_{2}$ and this effect is not clear once they are not administered with other respiratory depressants (11).

In our case, $2 \mathrm{mg}$ midazolam and $2 \mathrm{mg} / \mathrm{kg}$ iv ketamine were administered and spontaneous respiration was preserved. Because of the tendency to sleep in the postoperative period and regression of GCS, cranial tomography was taken. It was observed that a cerebellar mass was observed but the $4^{\text {th }}$ ventricle could not be seen. This suggests that administration of sedation in our case with an unknown tumor preoperatively increased ICP and contributed to the emergence of symptoms.

In our case, midazolam administered with ketamine possibly depressed the respiratory response to $\mathrm{CO}_{2}$ in the postoperative period, with the increase in partial carbon dioxide pressure contributing to secondary ICP increase.

\section{Conclusion}

We believe that the complaints of our patient 15 days before admission were secondary findings of increased ICP. Before administration of ketamine for sedation, preoperative evaluation should definitely include complete cranial nerve examination and questioning patients about symptoms that may be caused by increased ICP.

\section{Ethics}

Informed Consent: Consent form was filled out by all participants.

Peer-review: Externally peer-reviewed.

\section{Authorship Contributions}

Surgical and Medical Practices: Bengü Gülhan Aydın, Mehmet Akın. Concept: Bengü Gülhan Aydın, Mehmet Akın. Design: Bengü Gülhan Aydın. Data Collection or Processing: Bengü Gülhan Aydın, Mehmet Akın, Dilek Okyay, Özcan Pişkin. Analysis or Interpretation: Gamze Küçükosman, Bengü Gülhan Aydın, Hilal Ayoğlu. Literature Search: Murat Çimencan, Hilal Ayoğlu. Writing: Bengü Gülhan Aydın.

Conflict of Interest: No conflict of interest was declared by the authors.

Financial Disclosure: The authors declared that this study has received no financial support. 


\section{References}

1. Sehdev RS, Symmons DA, Kindl K. Ketamine for rapid sequence induction in patients with head injury in the emergency department. Emerg Med Australas 2006;18:37-44.

2. Özköse Z. Anesthesia For Posterior Fossa Surgery. Turkiye Klinikleri J Anest Reanim-Special Topics 2008;1:15-26.

3. Lewine WC, Allain RM, Alston TA, et al. Clinical Anesthesia Procedures of the Massachusetts General Hospital 8th eds ed. Lippincott Williams \& Wilkins2014. p.155.

4. Gardner AE, Dannemiller FJ, Dean D. Intracranial cerebrospinal fluid pressure in man during ketamine anesthesia. Anesth Analg 1972;51:741-5.

5. Lockhart $\mathrm{CH}$, Jenkins JJ. Ketamine-induced apnea in patients with increased intracranial pressure. Anesthesiology 1972;37:92-3.

6. Crumrine RS, Nulsen FE, Weiss MH. Alterations in ventricular fluid pressure during ketamine anesthesia in hydrocephalic children. Anesthesiology 1975;42:758-61.
7. Shaprio HM, Wyte SR, Harris AB. Ketamine anaesthesia in patients with intracranial pathology. $\mathrm{Br} J$ Anaesth 1972;44:1200-4.

8. Himmelseher S, Durieux ME. Revising a dogma: ketamine for patients with neurological injury? Anesth Analg 2005;101:524-34.

9. Belopavlovic M, Buchthal A. Modification of ketamineinduced intracranial hypertension in neurosurgical patients by pretreatment with midazolam. Acta Anaesthesiol Scand 1982;26:458-62.

10. Mayberg TS, Lam AM, Matta BF, et al. Ketamine does not increase cerebral blood flow velocity or intracranial pressure during isoflurane/nitrous oxide anesthesia in patients undergoing craniotomy. Anesth Analg 1995;81:84-9.

11. Butterworth JF, Mackey DC, Wasnick JD. Morgan Mikhail'Clinical Anesthesiology. Clinical Pharmacology 5th Ed: McGraw-Hill Lange; 2015; p.181. 